Tropical Journal of Pharmaceutical Research May 2017; 16 (5): 1181-1186

ISSN: $1596-5996$ (print); 1596-9827 (electronic)

(C) Pharmacotherapy Group, Faculty of Pharmacy, University of Benin, Benin City, 300001 Nigeria.

All rights reserved.

Available online at http://www.tjpr.org

Original Research Article

http://dx.doi.org/10.4314/tjpr.v16i5.28

\title{
Hypercalcaemia in patients with breast cancer: Patterns and treatment outcomes among in-patients in a Malaysian tertiary healthcare facility
}

\author{
Hassan Bassam and Aziz Zoriah \\ Department of Pharmacy, Faculty of Medicine, University of Malaya, 50603, Kuala Lumpur, Malaysia
}

*For correspondence: Email: bassamsunny@yahoo.com; Tel: +60164230950

Sent for review: 19 August 2016

Revised accepted: 7 April 2017

\begin{abstract}
Purpose: To assess the patterns of use of bisphosphonate therapies for hypercalcaemia in breast cancer patients, and their outcomes.

Methods: A retrospective chart review study of breast cancer patients hospitalised between 2009 and 2014 at Penang Hospital, a public tertiary hospital in Malaysia was conducted. Patients with mild (total serum calcium = 10.5 - $11.9 \mathrm{mg} / \mathrm{dl})$; moderate $(12-12.9 \mathrm{mg} / \mathrm{dl})$, and severe ( $\geq 13 \mathrm{mg} / \mathrm{dl}$ ) hypercalcaemia at cancer diagnosis or during cancer treatment were included. Relevant data were extracted from medical records analyzed statistically.

Results: From the records, 1,023 breast cancer patients were identified, 164 of which had hypercalcaemia at cancer diagnosis or during cancer treatment. About $25 \%$ of the hypercalcaemic patients had advanced-stage cancer, while $20 \%$ had severe hypercalcaemia. Regarding the pattern of bisphosphonate use, the results showed that more than half of the patients received pamidronate as first-line treatment; about a quarter were treated with zoledronic acid, while others received only normal saline. These treatments produced significant reductions in serum calcium levels relative to baseline values.

Conclusion: Although zoledronic acid is considered as the treatment of choice for hypercalcemia of malignancy, the current study found that the first line treatment used for hypercalcemia is pamidronate, mainly because its cost is lower than that of zoledronic acid.
\end{abstract}

Keywords: Pamidronate, Zoledronic acid, Bisphosphonates, Calcium levels

Tropical Journal of Pharmaceutical Research is indexed by Science Citation Index (SciSearch), Scopus, International Pharmaceutical Abstract, Chemical Abstracts, Embase, Index Copernicus, EBSCO, African Index Medicus, JournalSeek, Journal Citation Reports/Science Edition, Directory of Open Access Journals (DOAJ), African Journal Online, Bioline International, Open-J-Gate and Pharmacy Abstracts

\section{INTRODUCTION}

Hypercalcaemia is associated more with breast cancer than other cancers [1,2]. It is a lifethreatening condition characterised by serum calcium levels greater than $10.5 \mathrm{mg} / \mathrm{dL}$, and serum albumin concentrations lower than $4 \mathrm{~g} / \mathrm{dL}$ $[1,2]$.

Hypercalcaemia can occur in cancer patients with or without bone metastasis. The main mechanism of hypercalcaemia in these patients involves pathological bone resorption through secretion of cytokines such as parathyroid hormone-related protein (PTHrP), which leads to activation and differentiation of osteoclast cells [3-5].

In the last decade, many studies looked at the main risk factors for hypercalcaemia. Some of these risks, such as cancer stage, tumour size, and metastasis, were associated with incidence and/or severity of hypercalcaemia, but few studies have focused on the effectiveness of 
different hypercalcaemia treatments, which remains controversial [5-8]. Thus there is need for more studies to assess the pattern of use, effectiveness of different treatments, with a view to guiding clinical management of hypercalcaemia, and reducing mortalities associated with the disease [9]. Iwase and colleagues have since 2001, highlighted this dearth of information on hypercalcaemia treatment, particularly at different stages of solid cancer [10].

Bisphosphonates (such as alendronate, ibandronate, pamidronate, and zoledronic acid) are osteoclast inhibitors. They are currently used in oncology particularly for patients with hypercalcaemia due to bone metastatic breast cancer. Several studies conducted in various parts of the world have demonstrated the beneficial effects of bisphosphonates in hypercalcaemic patients $[11,12]$. While clinical trials support the use of bisphosphonates in breast cancer patients with hypercalcaemia, documentation of their day-to-day use i.e., pattern of use in clinical practice in Malaysia is still limited. Moreover, various studies indicate that further studies are needed to clarify effectiveness, pattern of use, how best to monitor treatment, and how to use bisphosphonates in a cost-effective manner among breast cancer patients [11,12]. Therefore, the aim of the present study was to review the pattern of use of bisphosonate therapies for hypercalcaemia in breast cancer patients, and their overall effects on hypercalcaemia.

\section{METHODS}

\section{Study design and setting}

Authors conducted a retrospective chart review between 2009 and 2014 at Penang Hospital, located in the State of Penang Island, Malaysia. Penang Hospital is the largest public hospital in North Malaysia, and a referral centre for cancer patients.

\section{Ethical approval}

This study was approved by the National Medical Research Register, Research and Technical Support, Level 12, Ministry of Health Malaysia (no. NMRR-10-59-5057), and international guidelines for human studies were followed [13].

\section{Patients and data}

Patients admitted to Penang Hospital between 2009 and 2014 were eligible for inclusion in this study if they were aged 18 years or above, and had a diagnosis of primary or advanced breast cancer. Early stages or primary stages of breast cancer include stages I, II, and III; while stage IV is the advanced stage $[14,15]$. To ensure a new diagnosis, patients were excluded if before the reference episode they had had any diagnosis of hypercalcemia or had used any antihypercalcemia drug. Moreover, patients were only included in this analysis if they had a calcium level measurement at baseline before starting anti-hypercalcemia treatment and at the reference time point. Also they were included if they had diagnosis of hypercalcaemia (serum calcium level above $10.5 \mathrm{mg} / \mathrm{dL}$ or greater than $2.5 \mathrm{mmol} / \mathrm{L}$ ) at cancer diagnosis or during cancer treatment; and had a normal or almost normal levels of alanine aminotransferase ALT), aspartate aminotransferase (AST), and serum total bilirubin.

Patients were considered ineligible if they had used thiazides or furosemide diuretics or calcitonin 7 days prior to the study; or had a diagnosis of hyperparathyroidism, hyperthyroidism, adrenal insufficiency, renal impairment or failure; or had haematological malignancy such as multiple myeloma, nonHodgkin lymphoma or Hodgkin lymphoma; or had thyroid or kidney cancer [16-18].

\section{Hypercalcaemia treatment data}

Information about treatment was obtained from medical records and software data which showed the time and all the required data related with the treatment type, dose, time and duration. Patients were classified on the basis of treatment received i.e. normal saline, pamidronate $(90 \mathrm{mg}$ via $2 \mathrm{~h}$ infusion) or zoledronic acid (4 $\mathrm{mg}$ via 15 minutes infusion).

\section{Classification of hypercalcaemia}

Serum calcium levels were collected before and after start using anti-hypercalcemia treatment i.e., base line. When serum calcium level between $10-5-11.9 \mathrm{mg} / \mathrm{dL}$ it will be considered as mild hypercalcemia. While, when it is between $12-12.9 \mathrm{mg} / \mathrm{dL}$ it will be considered as moderate hypercalcemia, and severe hypercalcemia will be considered when calcium value is $\geq 13 \mathrm{mg} / \mathrm{dL}$ [3].

\section{Statistics}

Data analysis was performed using Statistical Package of Social Science (SPSS $\AA$ ) version 20. Descriptive statistics were used for demographic and clinical characteristics of the patients included. A one-way repeated measures ANOVA 
was conducted to compare means of calcium levels before start using anti-hypercalcemia treatment (i.e., at baseline) and after hypercalcaemia treatments at three different times: Time 1 (with first dose; started after hypercalcemia diagnosis immediately), Time 2 (with second dose; started after 3 - 4 weeks from the first dose), and at Time 3 (with third dose; started after 3 - 4 weeks after the second dose) of treatment.

\section{RESULTS}

\section{Patient characteristics}

A total of 1,023 patients diagnosed with breast cancer were treated in Penang Hospital during the study period. Among these, 164 were diagnosed with hypercalcaemia at cancer diagnosis or during cancer treatment, and were therefore included in current study. Table 1 shows the characteristics of the patients. About half of the patients were Malay $81(49.4 \%)$, and about $73(45 \%)$ had stage III cancer. Majority of them $127(77.4 \%)$ did not have metastasis. More than half $93 \quad(56.7 \%)$ were placed on pamidronate, while about a quarter 42 (25.6\%) received zoledronic acid. The mean age (years) of the patients was 54.1 years $(S D=11.2)$. The youngest patient was 22 years old while the oldest was 73 years old. More than half 93 (56.7 $\%)$ of the 164 patients with hypercalcaemia had moderate hypercalcaemia, while only 25 (15.3 $\%$ ) had severe hypercalcaemia (Table 1).

\section{Pattern of use and treatment effect on serum calcium levels}

As it is obvious majority of the hypercalcemic patients were treated with pamidronate 93 (56.7 $\%)$ i.e., first line treatment, followed by zoledronic acid $42(25.6 \%)$, and finally came normal saline $29(17.7 \%)$.

The initial calcium level and choice of initial treatment were related in some instances, for example pamidronate was more likely to be given to patients with moderate hypecalcemia. Zoledronic acid was mainly given for those who suffered from severe hypercalcemia. While, normal saline mainly was given to those with mild hypercalcemia. For patients given just normal saline, there was a significant effect for time, Wilks' Lambda $=0.19, \mathrm{~F}(3,26)=36.82, p<$ .0001 , multivariate partial eta squared $=0.81$. Similarly, for patients treated with pamidronate, there was a single effect for time. Wilks' Lambda $=0.07, \mathrm{~F}(3,90)=411.23, p<.0001$, multivariate partial eta squared $=0.93$. Likewise, for patients treated with zoledronic acid there was also significant effect of time, Wilks' Lambda $=0.05, \mathrm{~F}$ $(3,39)=251.04, p<.0001$, multivariate partial eta squared $=0.95$.

Hypercalcaemia in the breast cancer patients was significantly reduced by each treatment (Table 2). Even the three treatments used i.e., pamidronate, zoledronic acid, and normal saline showed significant reduction in calcium level. But zoledronic acid is the most effective and superior compare with the pamidronate and normal saline in decreasing calcium level.

\section{DISCUSSION}

While clinical trials support the use of bisphosphonates in breast cancer patients with hypercalcaemia [17], data on their use in clinical practice is limited. Based on literature review, the present study is the first to show that the pattern of anti-hypercalcemia treatment use among

Table 1: Characteristics of the breast cancer patients studied $(n=164)$

\begin{tabular}{|c|c|c|c|c|c|c|c|}
\hline Race & $\begin{array}{l}\text { Marital } \\
\text { status }\end{array}$ & $\begin{array}{l}\text { Educational } \\
\text { status }\end{array}$ & $\begin{array}{l}\text { Cancer } \\
\text { stage }\end{array}$ & Metastasis & Bone scan & $\begin{array}{l}\text { Severity of } \\
\text { hypercalcemia }\end{array}$ & $\begin{array}{l}\text { Type of } \\
\text { treatment }\end{array}$ \\
\hline Malay & Married & Primary & $\mathrm{I}$ & Yes & Yes & Mild & Normal \\
\hline $81(49.4)$ & $77(47)$ & $28(17)$ & $11(6.7)$ & 37 (22.6) & 23 (14.02) & $46(28.0)$ & $\begin{array}{l}\text { Saline } \\
29(17.7)\end{array}$ \\
\hline Chinese & Divorced & Secondary & II & No & No & Moderate & Pamidronate \\
\hline $64(39.0)$ & $23(14)$ & $43(26.2)$ & 43 (26.2) & $127(77.4)$ & $\begin{array}{c}141 \\
(85.98)\end{array}$ & $93(56.7)$ & $93(56.7)$ \\
\hline \multirow[t]{2}{*}{$\begin{array}{l}\text { Indian } \\
19(11.6)\end{array}$} & $\begin{array}{l}\text { Widow } \\
35(21.3)\end{array}$ & $\begin{array}{l}\text { Diploma } \\
59(36)\end{array}$ & $\begin{array}{c}\text { III } \\
73(44.5)\end{array}$ & & & $\begin{array}{l}\text { Severe } \\
25 \text { (15.3) }\end{array}$ & $\begin{array}{l}\text { Zoledronic } \\
\text { acid } \\
42(25.6)\end{array}$ \\
\hline & $\begin{array}{l}\text { Single } \\
29(17.7)\end{array}$ & $\begin{array}{l}\text { College } \\
26(16) \\
\text { High } \\
\text { Education } \\
8(4.8)\end{array}$ & $\begin{array}{c}\text { IV } \\
37(22.6)\end{array}$ & & & & \\
\hline
\end{tabular}


Table 2: Calcium levels at baseline, first dose, second dose, and third dose for patients treated with normal saline, pamidronate, and zoledronic acid

\begin{tabular}{lllll}
\hline \multirow{2}{*}{ Treatment } & \multicolumn{3}{c}{ Number and Mean calcium levels of patients (mg/dL) } \\
\cline { 2 - 5 } & Baseline & $\begin{array}{l}\text { Time 1 } \\
\text { (First dose) }\end{array}$ & $\begin{array}{l}\text { Time 2 } \\
\text { (Second dose) }\end{array}$ & $\begin{array}{l}\text { Time 3 } \\
\text { (Third dose) }\end{array}$ \\
\hline Pamidronate & 93 & $12.6(0.7)$ & $12.1(0.6)$ & $11.5(0.6)$ \\
Zoledronic acid & 42 & $13.0(0.7)$ & $12.6(0.7)$ & $11.9(0.5)$ \\
Normal saline & 29 & $11.2(0.3)$ & $10.9(0.3)$ & $10.6(0.3)$ \\
\hline
\end{tabular}

Values are mean $\pm S D(p \leq 0.05)$

breast cancer patients in Malaysia. Findings showed that more than half of the hypercalcaemic breast cancer patients mainly those who suffered from moderate hypercalcemia and few of those who suffered from severe one were treated with pamidronate (as a first-line treatment) than with zoledronic acid, although the two drugs significantly reduced calcium levels from baseline values. It is worth noting that patients with severe hypercalcaemia either received pamidronate or zoledronic acid. Normal saline alone is frequently used as an initial treatment for overcoming dehydration and to compensate for fluid loss due to polyuria. The use of normal saline is optional, and is most common for patients with asymptomatic mild hypercalcaemia under observation prior to commencement of their anti-neoplastic treatments. Normal saline is also optional for patients who already show clinical signs and symptoms of hypercalcaemia $[18,19]$.

The apparent preference for pamidronate observed in this study, could probably be due to its lower cost. Indeed the generic version of pamidronate is 10 times less expensive than zoledronic acid [20]. In a retrospective study conducted by Spizzo and his colleagues in which routine uses of pamidronate and zoledronic acid were compared in patients with non-small cell lung cancer (NSCLC), it was reported that pamidronate was a well-tolerated and costeffective alternative to zoledronic acid [21]. These researchers also recommended that randomised studies be carried out to compare various bisphosphonate treatments with a view to determining the best treatment for NSCLC patients with bone metastasis. Other studies showed that the frequency and potency of pamidronate use are parallel to, or exceed those of zoledronic acid, especially among multiple myeloma or metastatic breast cancer patients [22]. On the other hand, results from some studies suggest that zoledronic acid is more frequently used than pamidronate because it is more potent and is associated with fewer side effects. Sanfilippo et al compared the effectiveness of zoledronic acid and pamidronate on survival of patients with multiply myeloma
[23]. They found that zoledronic acid was superior to pamidronate, since patients receiving zoledronic acid had $22 \%$ mortality reduction, compared to those on pamidronate [35]. Other studies showed that two low doses of zoledronic acid (4 mg and $8 \mathrm{mg}$ ) are superior to a single, higher dose of pamidronate $(90 \mathrm{mg})$ in treating patients suffering from moderate and severe hypercalcaemia $[12,20,24]$.

However, present study (i.e. non-randomised) was not designed to compare efficacies of pamidronate and zoledronic acid or treatment regimens, but only to review patterns of their clinical uses for treating hypercalcaemia and their overall effects on serum calcium levels. Very few patients in present study had bone scan. It was performed only when breast cancer was at advanced stage or when patients complained of pain in the bones. Indeed, de la Cueva et al [25] have advised that bone scan is not necessary in the early stages of breast cancer, but is mandatory for patients with stage IIB cancer, and tumour size equal to or more than $2 \mathrm{~cm}$. However, a bone scan is useful for identifying the aetiology of hypercalcaemia because it may be either due to bone metastases or PTHrP produced by cancer tissues [25].

\section{Limitations of the study}

There are several limitations to the present study. First the sample demography reflects Penang population, and therefore may not be generalized to hospitals or populations in other areas. Secondly, our inclusion criteria required that the patient received only bisphosphonates, and excluded patients treated with bisphosphonates and furosemide, thus reducing the number of breast cancer patients with hypercalcaemia in the study. Moreover, this study is a retrospective chart review; the primary data source is clinical records. Since clinical records are not designed for research, the findings may be limited by the degree of accuracy and completeness of the clinical records. 


\section{CONCLUSION}

The findings of the present study show that pamidronate is the most widely prescribed antihypercalcemic treatment (i.e., first-line treatment) probably because of its relatively lower cost.

\section{DECLARATIONS}

\section{Acknowledgement}

The authors would like to thank all the hospital staff for their cooperation and their assistance in carrying out this study. Thanks are also due to all the staff of the Oncology Clinic and the Records Office of Penang hospital for helping to access patients' files.

\section{Conflict of Interest}

No conflict of interest associated with this work.

\section{Contribution of Authors}

The authors declare that this work was done by the authors named in this article and all liabilities pertaining to claims relating to the content of this article will be borne by them.

\section{Open Access}

This is an Open Access article that uses a funding model which does not charge readers or their institutions for access and distributed under the terms of the Creative Commons Attribution License (http://creativecommons.org/licenses/by/ 4.0) and the Budapest Open Access Initiative (http://www.budapestopenaccessinitiative.org/rea d), which permit unrestricted use, distribution, and reproduction in any medium, provided the original work is properly credited.

\section{REFERENCES}

1. Ericson K. Hypercalcemia. In: Olendorf D.; Jeryan, Christine B.; Boyaden K., editors. Gale encyclopedia of medicine. Detroit, MI: Gale Research; 1999. p. 15001503.

2. Helft PR, Rudin CM. Metabolic and electrolyte complications of malignancy. In: Vokes, Everett E.; Golomb, Harvey M., editors. Oncologic therapies. Chicago: Springer-Verlag Berlin Heidelberg; 1999. $p$. 244-254.

3. Hassan B, Yusoff, ZB, Hassali MA, Saad O, Weiderpass $E$. Impact of chemotherapy on hypercalcemia in breast and lung cancer patients. Asian Pac J Cancer Prev 2012; 13(9): 4373-4378.
4. Holecki M, Skorupa A, Dulawa J, Chudek J. Hypercalcemia in patients treated with oral bisphosphonates for tumor-induced osteolysis. Maced $J$ Med Sci 2013; 1(1): 54-58.

5. Maier JD, Levine SN. Hypercalcemia in the intensive care unit: a review of pathophysiology, diagnosis, and modern therapy. J Intensive Care Med 2015; 30(5): 235252.

6. Yip CH, Pathy B, Teo SH. A Review of breast cancer research in Malaysia. Med J Malaysia 2014; 69: 8-22.

7. Erdogan B, Cicin I. Medical treatment of breast cancer bone metastasis: from bisphosphonates to targeted drugs. Asian Pac J Cancer Prev 2014; 15(4): 15031510.

8. Mundy GR, Guise TA. Hypercalcemia of malignancy. Am J Med Sci 1997; 103(2): 134-145.

9. Phimphilai M. Hypercalcemia in a hospital population: a retrospective study of 52 cases. Chiang Mai Med $J$ 2010; 49(1): 27-34.

10. Iwase $M$, Kurachi $Y$, Kakuta S, Sakamaki H, NakamuraMitsuhashi M, Nagumo M. Hypercalcemia in patients with oral squamous cell carcinoma. Clin Oral Investig 2001; 5(3): 194-198.

11. Theriault RL, Lipton A, Hortobagyi GN, Leff R, Glück $S$, Stewart JF. Pamidronate reduces skeletal morbidity in women with advanced breast cancer and lytic bone lesions: a randomized, placebo-controlled trial. Protocol 18 Aredia Breast Cancer Study Group. J Clin Oncol 1999; 17(3): 846-854.

12. Rosen LS, Gordon D, Kaminski M, Howell A, Belch A, Mackey J. Zoledronic acid versus pamidronate in the treatment of skeletal metastases in patients with breast cancer or osteolytic lesions of multiple myeloma: a phase III, double-blind, comparative trial. Cancer $J$ 2001; 7(5): 377-387.

13. Ethics and research on human subjects: International guidelines. J Med Ethics. 1995; 21(6): 363-364. PMCID: PMC1376838.

14. Booth CM, Clemons M, Dranitsaris G, Joy A, Young $S$, Callaghan $W$. Chemotherapy-induced nausea and vomiting in breast cancer patients: a prospective observational study. J Support Oncol 2007; 5(8): 374380.

15. Hassan BA, Yusoff ZB. Genetic polymorphisms in the three Malaysian races effect granisetron clinical antiemetic actions in breast cancer patients receiving chemotherapy. Asian Pac J Cancer Prev 2011; 12(1): 185-191.

16. LeGrand SB, Leskuski D, Zama I. Narrative review: furosemide for hypercalcemia: an unproven yet common practice. Ann Intern Med 2008; 149(4): 259-263.

17. Seccareccia D. Cancer-related hypercalcemia. Can Fam Physician 2010; 56(3): 244-246.

18. Rosner MH, Dalkin AC. Onco-nephrology: the pathophysiology and treatment of malignancyassociated hypercalcemia. Clin J Am Soc Nephrol 2012; 7(10): 1722-1729. 
19. Bob TL, Mathew HW, Nick P. Treatment and prevention of bone metastases from breast cancer: $A$ comprehensive review of evidence for clinical practice. $J$ Clin Med 2014; 3(1): 1-24.

20. Major P, Lortholary A, Hon J, Abdi E, Mills G, Menssen $H D$, Yunus F, Bell R, Body J, Quebe-Fehling E. et al., Zoledronic acid is superior to pamidronate in the treatment of hypercalcemia of malignancy: A pooled analysis of two randomized, controlled clinical trials. J ClinOncol 2001; 19(2): 558-567.

21. Spizzo G, Seeber A, Mitterer $M$. Routine use of pamidronate in NSCLC patients with bone metastasis: results from a retrospective analysis. Anticancer Res 2009; 29(12): 5245-5250.
22. Berenson JR. Recommendations for Zoledronic acid treatment of patients with bone metastases. Oncologist 2005; 10(1): 52-62.

23. Sanfilippo KM, Gage B, Luo S, Weilbaecher $K$, Tomasson $M$, Vij R. Comparative effectiveness on survival of zoledronic acid versus pamidronate in multiple myeloma. Leuk Lymphoma 2015; 56(3): 615621.

24. Berger AM.; Shuster JL.; Von Roenn JH. Principles and practice of palliative care and supportive oncology. Philadelphia: Lippincott Williams and Wilkins; 2007; $p$ 551.

25. de la Cueva L, Liévano $P$, Navarro $P$, Arroyo $E$, Añaños $M$, González M. Indication for bone scans in early breast cancer staging. Rev Esp Med Nucl. 2009; 28(6): 273277. 